\title{
Production of interferon by the conceptus in red deer Cervus elaphus
}

\author{
K. J. Demmers ${ }^{1}$, S. Kaluz ${ }^{1+}$, D. W. Deakin ${ }^{2}$, H. N. Jabbour ${ }^{3}$ and A. P. F. Flint ${ }^{1 *}$ \\ ${ }^{1}$ Division of Animal Physiology, School of Biological Sciences, University of Nottingham, Sutton Bonington Campus, \\ Loughborough LE12 5RD, UK; ${ }^{2} A D A S$ Rosemaund, Preston Wynne, Hereford HR1 3PG, UK; and ${ }^{3} M R C$ Reproductive Biology Unit, \\ Centre for Reproductive Biology, 37 Chalmers Street, Edinburgh EH3 9EW, UK
}

\begin{abstract}
A type I interferon secreted by early sheep and cow conceptuses is responsible for the maternal recognition of pregnancy in these species. Interferon-tau (IFN $\tau$ ) acts locally on the maternal endometrium to prevent luteolysis and prolong progesterone secretion. The production of IFN $\tau$ was investigated in early pregnancy in red deer, Cervus elaphus. The oestrous cycles of 14 hinds were synchronized using intra-vaginal controlled internal progesterone-releasing devices. Hinds were run with a fertile stag, then slaughtered on either day $20(n=10)$ or day 22 after withdrawal of progesterone $(n=$ 11). Conceptuses were recovered after uterine excision and flushing with sterile saline. Conceptus RNA was reverse transcribed and amplified by PCR using primers designed from highly conserved regions of ovine and bovine IFN $\tau$ genes. The resulting PCR products were cloned and fully sequenced. Sequence comparisons indicate that the transcript characterized is closely related to the IFN $\tau$ and interferon-omega genes of bovids and giraffe, showing $>85 \%$ nucleotide sequence homology and $>74 \%$ predicted amino acid similarity with previously cloned genes. Northern blot analysis of total conceptus RNA using a homologous IFN $\tau$ probe confirmed the high expression of IFN $\tau$ which is encoded by a transcript of approximately 1 kilobase. Anti-viral activity was measured in uterine flushes from pregnant hinds using a cytopathic effect inhibition assay $\left(4.3 \times 10^{3} \pm 0.78 \times 10^{3} \mathrm{iu} \mathrm{ml}^{-1} ; n=14\right)$, but was not detectable in flushes from nonpregnant hinds $(n=7)$, confirming that preimplantation red deer conceptuses release interferons. This is the first demonstration of IFN $\tau$ expression in a cervid conceptus and provides evidence that IFN $\tau$ may be involved in the maternal recognition of pregnancy in red deer.
\end{abstract}

\section{Introduction}

Many species of deer are rare, endangered or threatened in their natural habitats (IUCN, 1996) and this, together with the increasing importance of commercial deer farming, has led to an interest in applying techniques such as artificial insemination, in vitro fertilization and embryo transfer to deer (Waldhalm et al., 1989; Fennessy et al., 1990, 1994; Wildt 1992; Berg et al., 1995). However, embryo transfer experiments have not always led to a high percentage of live births (Waldhalm et al., 1989; Fennessy et al., 1994), indicating a need for further knowledge of the physiological processes underlying early pregnancy in deer.

As is the case in sheep and cattle, the red deer blastocyst remains unattached to the endometrium for a relatively long period after conception. The conceptus must communicate with the mother to prevent regression of the corpus luteum at the end of the luteal cycle, well before the time of blastocyst attachment to the maternal endometrium. In the

\footnotetext{
* Correspondence.

${ }^{\dagger}$ Present address: Institute of Virology, Slovak Academy of Sciences, Dubravská cesta 6, 84246 Bratislava, Slovak Republic.

Received 23 February 1998.
}

domestic bovids, a type I interferon (IFN) secreted by the trophectoderm of the developing blastocyst has been identified as the embryonic signal responsible for preventing luteolysis (for review, see Roberts et al., 1992). This trophoblast interferon, interferon-tau (IFN $\tau$ ), is most closely related to the 172 amino acid IFN-omega (IFN $\omega$ ) subclass of interferons (Imakawa et al., 1987), and has anti-viral and antiproliferative properties (Roberts, 1989).

In sheep, the corpus luteum regresses as the result of release of the luteolytic hormone, prostaglandin $\mathrm{F}_{2 \alpha}\left(\mathrm{PGF}_{2 \alpha}\right)$, from the uterine endometrium late in the oestrous cycle (McCracken et al., 1972). A mixture of isoforms of IFN $\tau$ is secreted by the blastocyst into the uterine lumen (Godkin et al., 1982, 1984) which suppresses the normal pattern of pulsatile release of $\mathrm{PGF}_{2 \alpha}$ (Fincher et al., 1986) through inhibition of expression of oxytocin receptors in the uterine endometrium (Flint et al., 1991). This inhibition results in the prevention of luteolysis, ensuring the continued luteal secretion of progesterone required for the maintenance of pregnancy (Flint et al., 1994).

Characteristics of early conceptus development and endocrinology are not well established for red deer, Cervus elaphus. The hormonal basis of maternal recognition of 
pregnancy remains unclear in cervids, although pregnancy is known to be dependent on maintenance of the corpus luteum (Asher et al., 1996) but interferons may be involved in the establishment of early pregnancy (Flint 1995). Systemic administration of exogenous IFN $\alpha$ delays luteal regression in red deer hinds (Bainbridge et al., 1996), as it does in sheep and cattle (Stewart et al., 1989a; Plante et al., 1991). Furthermore, uterine flushings from pregnant red deer hinds contain anti-viral activity, suggesting the presence of IFN (Flint, 1995; Flint et al., 1997).

The aim of the present study was to determine whether IFN $\tau$ is expressed by preimplantation red deer blastocysts and to determine, by sequencing of cDNA, whether this protein is similar to that expressed in the Bovidae.

\section{Materials and Methods}

\section{Animals}

The study was conducted at ADAS Rosemaund Research Centre, Hereford $\left(52^{\circ} 10^{\prime} \mathrm{N}\right)$ in autumn 1995. A total of 21 mature (4-7 years of age) red deer hinds (Cervus elaphus) with a mean $( \pm$ SEM) live weight of $91.4 \pm 2.3 \mathrm{~kg}$ were kept in fenced grass paddocks.

\section{Experimental protocol}

Oestrus was synchronized in each hind by administration of progesterone by intravaginal pessary (Controlled Internal Drug-Releasing (CIDR) device, type G; $0.3 \mathrm{~g}$ progesterone per device; $\mathrm{CHH}$ Plastic Products Group Ltd, Hamilton, New Zealand). The first CIDR device was inserted for 8 days and was replaced with a second device for 4 days. The time of withdrawal of the second device was taken as day 0 , after which time hinds were run with a fertile stag. Animals were slaughtered on either day $20(n=10)$ or day $22(n=11)$, with the average live-weight of hinds slaughtered on each day being 91-92 kg. CIDR devices were inserted on 3 October 1995 (animals slaughtered on day 20) or 12 October 1995 (animals slaughtered on day 22).

\section{Collection of embryos}

The uterus was dissected from the surrounding tissue and the ovaries were checked for evidence of recent ovulation. The uterus was bisected at the cervical end and the two horns were separated. Sterile saline solution $(10-20 \mathrm{ml})$ was injected into the tip of each uterine horn through a blunt needle inserted into the uterine lumen. The flushing solution containing the embryo was collected into a sterile container from the cervical end. The embryo was removed and the saline was frozen immediately on dry ice and kept at $-70^{\circ} \mathrm{C}$ until needed for assay.

\section{PCR and cloning of deer trophoblast interferon}

Total RNA (5 $\mu \mathrm{g}$ ) extracted (Chomczynski and Saachi, 1987) from blastocysts was primed with random hexamer primers ( $3 \mu \mathrm{g} \mathrm{ml}^{-1}$, Gibco BRL, Uxbridge, Middlesex) and transcribed with Superscript RNase $H$ reverse transcriptase (Gibco). Single-stranded cDNA (one-twentieth of total) was amplified by PCR, using the following primers designed from conserved areas of previously sequenced ovine and bovine IFN $\tau$ genes: IFN $\tau$ sense primer: $5^{\prime}-\mathrm{GAG}$ AAT TCT CAG YCA GCC CRG CAG C-3' ( $Y=$ either $C$ or $T, R=G$ or A); IFN $\tau$ anti-sense primer: 5'-CGA AGC TTC AAG GTG AGT TCA GAT CTC C-3'. The expected PCR product size using the IFN $\tau$ primers was 635 base pairs (bp). A further sense primer, oTP-1 CDNA 5' primer (after Nephew et al, 1993; 5'-CCT GTC TGC AGG ACA GAA AAG ACT T-3') was used in combination with the IFN $\tau$ anti-sense primer, to give an expected PCR product of $444 \mathrm{bp}$. Primer location relative to a potential cap site of IFN $\tau$ cDNA (Nephew et al., 1993) was 30-54 for the IFN $\tau$ sense primer, $637-664$ for the IFN $\tau$ anti-sense primer and 221-245 for the oTP-1 sense primer. PCR was carried out in $25 \mu$ final volume using $0.625 \mathrm{U} \mathrm{Taq}$ DNA polymerase (Gibco), $2.5 \mu \mathrm{l} 10 \times$ buffer, $5 \mathrm{pM}$ each primer, $1.5 \mathrm{mmol} \mathrm{MgCl}_{2} \mathrm{l}^{-1}$ and $0.2 \mathrm{mmol} \mathrm{l}^{-1}$ of each of the four dNTPs. The following profile was used in the Omnigene Temperature Cycler (Hybaid, Teddington, Middlesex): 40 cycles of $94^{\circ} \mathrm{C}$ for $30 \mathrm{~s}, 60^{\circ} \mathrm{C}$ for $30 \mathrm{~s}$ and $72^{\circ} \mathrm{C}$ for $45 \mathrm{~s}$. PCR products were purified after excision from a $1 \%$ low-melting point gel using the US Bioclean MP kit (United States Biochemical, Cleveland, $\mathrm{OH}$ ). PCR products were cloned into the p-GEM-T Easy Vector (Promega Ltd, Southampton) or pBluescript II KS (Stratagene Ltd, Cambridge) and amplified in JM109 cells (Promega). Plasmid DNA was extracted using the Wizard mini-prep system (Promega) and both strands were fully sequenced using an automatic DNA sequencer using both plasmid and internal primers (ABI 373A, Perkin-Elmer, Applied Biosystems, Foster City, CA). Blastocyst RNA was checked for DNA contamination by PCR under the conditions detailed above without reverse transcription. The Lasergene Software Package was used for sequence manipulation including contig alignment, multiple sequence alignment and sequence comparisons using the Clustal Algorithm (DNAstar Inc., Madison, WI).

\section{Northern blot analysis of trophoblast RNA}

Total RNA $(20 \mu \mathrm{g})$ was separated on a $1 \%$ agaroseformaldehyde gel with an RNA marker (Promega) and transferred to Hybond $\mathrm{N}$ membrane (Amersham International Plc, Amersham, Bucks) by capillary blotting (Sambrook et al., 1989). A 635 bp PCR product raised from day 20 cDNA using IFN $\tau$ sense and anti-sense primers (see above) was labelled using the Megaprime DNA labelling system and $\left[\alpha-{ }^{32} \mathrm{P}\right] \mathrm{dCTP}$ (Amersham). Pre-hybridization was for $1 \mathrm{~h}$ and was followed by hybridization overnight at $42^{\circ} \mathrm{C}$ in solution containing $50 \%$ formamide, $5 \times$ SSPE $(20 \times$ SSPE is

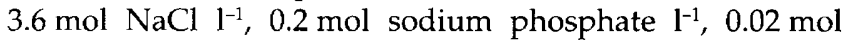
EDTA $1^{-1}$, pH 7.4), $5 \times$ Denhardt's (100 $\times$ Denhardt's is $2 \%$ BSA, $2 \%(\mathrm{w} / \mathrm{v})$ Ficoll and $2 \%(\mathrm{w} / \mathrm{v})$ polyvinylpyrrolidone), $0.5 \%(\mathrm{w} / \mathrm{v})$ SDS and $100 \mu \mathrm{g} \mathrm{ml}^{-1}$ denatured salmon sperm DNA (Sigma, Poole). Membranes were washed for $2 \times 10 \mathrm{~min}$ at room temperature in $2 \times \mathrm{SSC}\left(0.3 \% \mathrm{~mol} \mathrm{NaCl}^{-1}\right.$ containing $0.03 \%$ mol sodium citrate $\left.\mathrm{l}^{-1}\right) ; 0.1 \%(\mathrm{w} / \mathrm{v})$ SDS; for $1 \times 15 \mathrm{~min}$ 
at $65^{\circ} \mathrm{C}$ in $1 \times \mathrm{SSC} ; 0.1 \%$ SDS; for $1 \times 10 \mathrm{~min}$ at $65^{\circ} \mathrm{C}$ in $0.1 \times$ SSC; $0.1 \%$ SDS, and then autoradiographed for $48 \mathrm{~h}$. The RNA blot was washed in boiling $0.1 \%$ SDS to remove the probe and was re-probed with an $18 \mathrm{~S}$ riboprobe (Promega) labelled with [ $\left.\alpha{ }^{32} \mathrm{P}\right] \mathrm{dUTP}$ (Amersham), with hybridization and washing to a stringency of $0.1 \times \mathrm{SSC} ; 0.1 \% \mathrm{SDS}$ at $65^{\circ} \mathrm{C}$ and autoradiographed for $12 \mathrm{~h}$.

\section{Anti-viral assay}

Uterine flushings were analysed for anti-viral activity using a cytopathic effect inhibition assay (Meager 1987; Abayasekara et al., 1995). Briefly, cultures of Madin-Darby bovine kidney (MDBK) cells were exposed to dilutions of IFN standards or unknown samples before addition of Semliki Forest virus (SFV); the inhibitory effect of IFN on the cytopathic action of SFV was determined by measuring cell density. Each concentration of unknown was assayed in duplicate. All additions were made in culture medium containing $10 \%(\mathrm{v} / \mathrm{v})$ fetal calf serum, 50 iu penicillin $\mathrm{ml}^{-1}, 50$ $\mu \mathrm{g}$ streptomycin $\mathrm{ml}^{-1}$ and $2 \mathrm{mmol} \mathrm{L-glutamine} \mathrm{l}^{-1}$ in minimal essential medium with Earle's salts (Gibco); cultures were at $37^{\circ} \mathrm{C}$ in $5 \% \mathrm{CO}_{2}$ in air. The lowest concentration of SFV required to cause $100 \%$ cell death was initially determined by serial dilutions and culture under assay conditions, and this concentration was used throughout. Concentrations of bovine recombinant interferon- $\alpha \mathrm{I}_{1}$ (laboratory standard, Ciba-Geigy Ltd, Basel) were standardized against the First International Standard (1987), containing human recombinant IFN $\alpha I_{1}$ obtained from the National Institute of Biological Standards and Control (Potters Bar, Herts). The potency of the laboratory standard was $1.57 \mathrm{iu} \mathrm{ng}^{-1}$. Wells containing only cells (no virus controls) and cells plus virus (no IFN controls) were run on each plate and the mid-point between these values was used to calculate concentrations of IFN causing $50 \%$ inhibition of cytopathic effect. These end points were then expressed in terms of the International Standard and were corrected for flushing volume. The sensitivity of the assay was $50 \mathrm{iu} \mathrm{ml}{ }^{-1}$.

\section{Statistical analyses}

Results are expressed as means \pm SEM. Comparison between amounts of anti-viral activity, measured in flushings from either day 20 or day 22 pregnant deer, was carried out using Student's $t$ test. Densitometric scans of northern blots probed with either IFN $\tau$ or $18 \mathrm{~S}$ were analysed by $t$ test.

\section{Results}

\section{Sequencing}

Filamentous blastocysts were collected from five hinds on day 20 and nine hinds on day 22. RNA was extracted from four day 20 blastocysts and three day 22 blastocysts, and cDNA was prepared by reverse transcription. All samples showed amplification of the expected $635 \mathrm{bp}$ product after
PCR with the IFN $\tau$ primers, and of the expected 444 bp product using oTP-1 sense and IFN $\tau$ anti-sense primer (data not shown). The $635 \mathrm{bp} \mathrm{PCR}$ product from a day $20 \mathrm{cDNA}$ sample was cloned into p-GEM-T, and the 444 bp PCR product from a different day 20 cDNA sample was cloned into pBluescript. Both clones were fully sequenced in both directions and the $444 \mathrm{bp}$ sequence showed $100 \%$ nucleotide homology with a section of the $635 \mathrm{bp}$ sequence. The blastocyst RNA samples used did not produce amplified products without earlier reverse transcription, indicating that the PCR products were not amplified from contaminating genomic DNA in the samples. The CDNA sequence and deduced amino acid sequence for Cervus elaphus trophoblast interferon (cvIFN $\tau$ ) obtained from the 635 bp clone are shown (Fig. 1). The sequence indicates that $\operatorname{cvIFN} \tau$ has a 585 nucleotide open reading frame and encodes a putative 23 amino acid signal sequence and a 172 amino acid mature protein that are characteristic of both IFN $\tau$ and IFN $\omega$.

\section{Northern blot analysis}

Northern blot analysis of total RNA from day 20 and day 22 blastocysts demonstrated the presence of an mRNA species of approximately 1 kilobase $(\mathrm{kb})$ that hybridizes strongly to the [ $\left.\alpha-{ }^{32} \mathrm{P}\right] \mathrm{dCTP}-$ labelled IFN $\tau$ cDNA (Fig. 2). The relative amount of total RNA in each sample is illustrated by hybridization to the $18 \mathrm{~S}$ riboprobe. Densitometric scanning showed that the IFN:18S RNA ratio decreased between days 20 and 22 (mean ratio: day $20=0.49$; day $22=0.20$ ), suggesting that IFN mRNA decreased relative to total RNA at this time $(P<0.05)$.

\section{Anti-viral activity}

The anti-viral activity measured in uterine flushes is illustrated (Table 1). Uterine flushes from pregnant hinds show significant amounts of anti-viral activity $\left(4.3 \times 10^{3} \pm\right.$ $0.78 \times 10^{3} \mathrm{iu} \mathrm{ml}^{-1} ; n=14$ ), with those from non-pregnant hinds showing undetectable amounts ( $\left.<50 \mathrm{iu} \mathrm{ml}^{-1}, n=7\right)$. No significant difference in anti-viral activity was observed in the uterine flushings collected from day 20 and day 22 pregnant hinds $(P>0.1)$.

\section{Discussion}

The presence of significant anti-viral activity in uterine flushes from pregnant hinds indicates that red deer blastocysts release interferons, with amounts reported in the present study being comparable with those measured by Flint et al. (1997) from pregnant red deer hinds culled on the Isle of Rum. In domestic ruminants, the presence of IFN $\tau$ is reflected in anti-viral activity detected in uterine flushes (Pontzer et al., 1988; Roberts et al., 1989). However, amounts of anti-viral activity in red deer are lower than those measured in bovids, in which concentrations may reach $10^{6}$ units $\mathrm{ml}^{-1}$ (Flint et al., 1994). Lower anti-viral activity may be consistent with high endometrial sensitivity to IFN $\tau$. 
(a)

30 GAGAATCCTCAGCCAGCCCGgCAGCAGCCTCATCTTCCCC ATG GCC TTC GTG CTC Net Ala Phe Val Leu

85 TCT CTA CTG ATG GCC CTG GTG CTG GCC AGC TAC AGC CCA GGA GGG ser Leu Leu Met Ala heu Val Leu Ala Ser Tyr Ser Pro Gly Gly

130 TCC CTG GGC TGT GAC CTG TCT CAG AAC CAT GTG CTG CTT GGC AGG Ser Leu Gly Cys Asp Leu Ser Gln Asn His Val Leu Leu Gly Arg

175 CAG AAC CTC AAG CTC CTG GGC CAA ATG ACG AGA CTC TCC CCT CGC GIn Asn Leu Lys Leu Leu Gly Gin Met Thr Arg Leu ser Pro Arg

(b)

220 TTC TGT CTG CAG GAC AGA AAA GAC TTC GGT CTT CCC CAG GAG ATG phe Cys Leu Gln Asp Arg Lys Asp Phe Gly Leu Pro Gln Glu Met

265 GTG GAG GGC GGC CAG CTT CAG AAG GAC CAG GCC ATC TCT GTG CTC Val Glu Gly Gly Gln Leu Gln Lys Asp Gln Ala Ile Ser Val Leu

310 CAC GAG ATG CTC CAG CAA TGC TTC AAC CTC TTC CAC ACA GAG CGC His Glu Met Leu Gln Gln Cys phe Asn Leu phe His Thr Glu Arg

355 TCC TCT GCT GCC TGG GAC ACC ACC CTC CTG GAG CAG CTC CGC ACT Ser Ser Ala Ala Trp Asp Thr Thr Leu Leu Glu Gin Leu Arg Thr

400 GGA CTC CAT CAG CAG CTG GAC GAC CTG GAT GCC TGC CTG GGg CAG Gly Leu His Gln Gln Leu Asp Asp Leu Asp Ala Cys Leu Gly Gln

445 GTG ATG GGA AAG GAA GAC TCT GAC CTG AGA AGG ATG GGC CCC ACT Val Met Gly Lys Glu Asp Ser Asp Leu Arg Arg Met Gly pro Thr

490 CTG ACC GTG AAG AAG TAC TTC CAG GGA ATC CAC GTC TAC CTG CAA Leu Thr Val Lys Lys Tyr phe Gln Gly rle His val Tyr Leu Gin

535 GAG AAG GAA TAT AGC GAC TGC GCC TGG GAA ATC GTC CAA GTG GAG Glu Lys Glu Tyx ser Asp Cys Ala Trp Glu Ile Val Gln Val Glu

580 ATG ATG AGA GCT CTC TCT TCA ATA TCC AGg TTG CAA AAA AGg TTA Met Met Arg Ala Leu Ser Ser Ile Ser Arg Leu Gin Lys Arg Leu (c)

625 AGA AAG ATG GGT GGA GAT CTG AAC TCA CCT TGA AGCTTCG

Arg Lys Met Gly Gly Asp Leu Asn Ser Pro End

Fig. 1. The nucleotide sequence of cervine interferon-tau (IFN $\tau$ ) (numbered at left, after Nephew et al., 1993), showing the deduced amino acid sequence of the polypeptide (numbered at right). The position of a putative signal peptide, numbered S1-S23, is illustrated using bold type. Nucleotide sequences for primers used in PCR are underlined and labelled: (a) IFN $\tau$ sense, (b) oTP-1 cDNA 5 ' and (c) IFN $\tau$ anti-sense.

The presence of anti-viral activity in uterine flushings does not prove that a previously uninvestigated species produces blastocyst interferons that act as anti-luteolysins. Production of low concentrations of IFN by early conceptuses (usually detected as anti-viral activity) has been reported in a range of non-ruminant species (Roberts et al., 1990). This finding indicates that IFN production during pregnancy may be a fairly general phenomenon (Leaman and Roberts, 1992) with IFNs playing a role in the viral protection of conceptuses at the time of implantation ( $D^{\prime}$ Andrea et al., 1994). The pig conceptus spontaneously and intensively secretes IFN between day 12 and day 20 of pregnancy (Cross and Roberts 1989; Mirando et al., 1990). However, in pigs, there is no homologous IFNt mRNA expression in the conceptus (Charlier et al., 1989), as has been shown in deer. The size of the cvIFN $\tau$ mRNA (about $1 \mathrm{~kb}$ ), as measured by northern blotting, is consistent with the size of IFN $\tau$ mRNA in sheep and cattle (Charlier et al., 1989; Stewart et al., 1989b). Amounts of mRNA encoding cvIFN $\tau$ are lower in day 22 than day 20 blastocysts, which is in agreement with data 
(a)

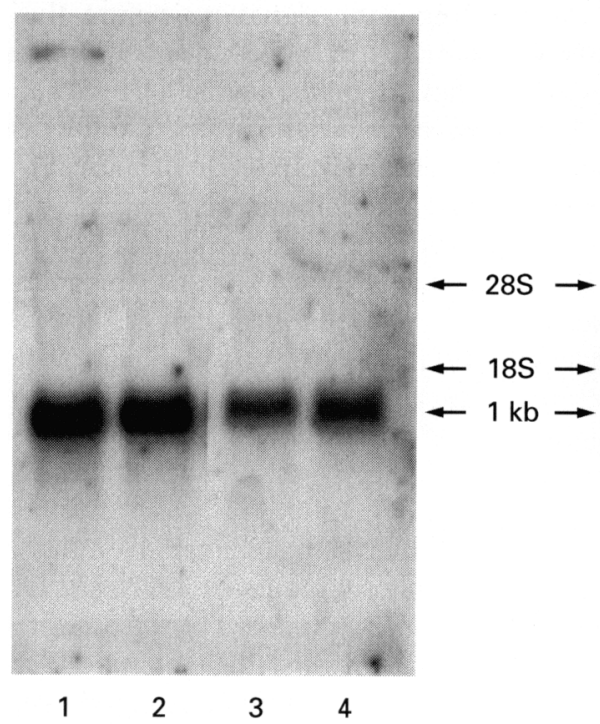

(b)

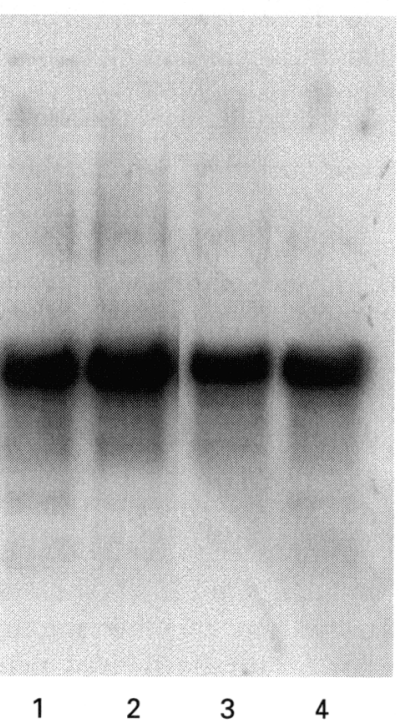

Fig. 2. Northern blot analysis of total RNA from day 20 and day 22 red deer blastocysts probed with (a) IFN $\tau$ cDNA probe and (b) 18S riboprobe. Lanes 1 and 2 contain total RNA from day 20 blastocysts, and lanes 3 and 4 contain RNA from day 22 blastocysts. The positions of ribosomal RNA are given as size indicators.

Table 1. Summary of results showing anti-viral activity of uterine flushes (iu ml-1) on day 20 and day 22 after removal of controlled internal drug-releasing devices in pregnant and non-pregnant red deer hinds

\begin{tabular}{lcc}
\hline & Pregnant & Non-pregnant \\
\hline Day 20 & $3.8 \times 10^{3} \pm 8.9 \times 10^{2}$ & nd \\
& $(n=5)$ & $(n=5)$ \\
Day 22 & $4.7 \times 10^{3} \pm 1.1 \times 10^{3}$ & nd \\
& $(n=9)$ & $(n=2)$ \\
\hline
\end{tabular}

$n$, number of hinds; nd, not detectable (anti-viral activity below sensitivity of assay). from sheep in which amounts of mRNA are maximal on days 14-15 and decrease by day 21 of pregnancy (Hansen et al., 1988; Charlier et al., 1989).

Further evidence that IFN $\tau$ functions in the maternal recognition of pregnancy in red deer is provided by the high expression of IFN $\tau$ mRNA in the blastocyst and by the similarity between the IFN sequenced here and previously sequenced IFN $\tau$ and IFN $\omega$ genes from other species. The coding region of the nucleotide sequence of $\operatorname{cvIFN} \tau$ is $>85 \%$ homologous and the predicted amino acid sequence is $>74 \%$ homologous with IFN $\tau$ from sheep, cows, goats, musk ox and giraffe (Table 2). CvIFN $\tau$ also shows high nucleotide sequence similarity with previously sequenced ovine and bovine IFN $\omega$ genes in the coding region. The possibility that the IFN sequenced here was derived from a genomic IFN $\omega$

Table 2. Comparison of sequence similarities of IFN $\tau$ and IFN $\omega$ in Ruminantia

\begin{tabular}{|c|c|c|c|c|c|c|c|c|c|}
\hline & CvIFN $\tau$ & BoIFN $\tau$ & OvIFN $\tau$ & $\mathrm{CaIFN} \tau$ & $\operatorname{OmIFN} \tau$ & GiIFN $\tau$ & BoIFN $\omega$ & OvIFN $\omega$ & $\begin{array}{c}\text { Accession } \\
\text { number }\end{array}$ \\
\hline CvIFN $\tau$ & & 87.4 & 85.5 & 85.4 & 85.4 & 85.9 & 87.4 & 88.8 & AJ000638 \\
\hline${ }^{\mathrm{a} B o I F N \tau}$ & 81.1 & & 88.8 & 88.3 & 88.3 & 89.5 & 99.0 & 84.5 & M31556 \\
\hline${ }^{\mathrm{b}} \mathrm{OvIFN} \tau$ & 78.1 & 81.6 & & 96.3 & 93.2 & 85.5 & 88.8 & 82.5 & M88773 \\
\hline${ }^{\circ} \mathrm{CaIFN} \tau$ & 74.0 & 80.6 & 90.8 & & 94.0 & 85.0 & 88.3 & 82.1 & M73243 \\
\hline${ }^{\varsigma} \mathrm{OmIFN} \tau$ & 75.5 & 80.6 & 87.8 & 88.3 & & 84.7 & 88.4 & 83.0 & M73244 \\
\hline${ }^{\mathrm{d}}$ GilFN $\tau$ & 78.6 & 85.2 & 77.0 & 75.5 & 75.5 & & 89.5 & 82.1 & U55050 \\
\hline${ }^{e} B o I F N \omega$ & 81.1 & 98.0 & 82.1 & 81.1 & 81.1 & 85.2 & & 84.7 & M60913 \\
\hline${ }^{b} \mathrm{OvIFN} \omega$ & 80.6 & 75.0 & 70.9 & 68.4 & 69.4 & 70.9 & 74.5 & & X59067 \\
\hline
\end{tabular}

Percentage nucleotide sequence (upper right) and amino acid sequence (lower left) similarities between each pair of IFN in the coding region are shown. Where multiple clones of IFN $\tau$ have been isolated from a single species, the clone that has highest sequence similarity to deer IFN $\tau$ was chosen for this comparison. Cv, Cervus elaphus; Bo, Bos taurus; Ov, Ovis aries; Ca, Capra hircus; Om, Ovis moschatus; Gi, Giraffa camelopardalis. Sequence data are from: "Imakawa et al., 1989, 'Nephew et al., 1993, 'Leaman and Roberts, 1992, 'Liu et al., 1996 and ${ }^{\circledR} H a n s e n$ et al., 1991. 
gene rather than from IFN $\tau$ mRNA is unlikely, as genomic DNA contamination of the RNA used was ruled out. However, it is possible that the high amount of mRNA detected in the blastocyst represents an IFN $\omega$ also expressed in the adult. Owing to the high expression of IFN mRNA in the red deer blastocyst, and in view of the sequence similarity between IFN $\tau$ and IFN $\omega$, the term IFN $\tau$ has been used to describe the transcript isolated here.

The similarity of cvIFN $\tau$ to ovine and bovine IFN $\omega$ may explain why Leaman and Roberts (1992) were unable to isolate an IFN $\tau$ gene from white-tailed deer (Odocoileus virginianus) genomic DNA by PCR, despite Southern blotting indicating that this species was likely to possess such a gene. The primers used were designed to reduce the probability of amplifying IFN $\omega$ genes instead of IFN $\tau$ genes.

The predicted primary sequence of cvIFN $\tau$ includes cysteine residues at positions 1,29, 99 and 139 . The cysteines at these four sites are conserved in all other mammalian IFN $\alpha$, IFN $\omega$ and IFN $\tau$, except for giraffe IFN $\tau$ which lacks Cys99 (Liu et al., 1996), and they form two specific disulphide bridges (Cys1-Cys99 and Cys29-Cys139) in human IFN $\alpha$ (Wetzel, 1981). The cysteine residues at positions 29 and 139 are essential for anti-viral activity (Shafferman et al., 1987). Most IFN $\tau$ have a fifth Cys at position 86 which is absent from the cvIFN $\tau$ reported here. However, the musk ox IFN $\tau$ also lacks this Cys (Leaman and Roberts 1992). In both the musk ox sequence and the sequence reported here, this Cys is replaced by an Arg residue, as it is in sheep IFN $\omega$ (Nephew et al., 1993); in bovine IFN $\omega$, there is a Leu at this position (Hansen et al., 1991).

The translation initiation sequence TCCCC is identical to that of bovine IFN $\alpha$, and the sequence of the signal peptide differs by only two amino acids (Val ${ }^{\mathrm{S14}} \rightarrow \mathrm{Ala} ; \mathrm{Gly}^{\mathrm{S} 17} \rightarrow \mathrm{Ser}$ ) when compared with ovine and bovine IFN $\tau$ genes. A peptidase recognition site (Ser-Leu-Gly) is present at the junction between the signal peptide and the mature protein, as in all other IFN $\tau$ and IFN $\omega$. CvIFN $\tau$ does not contain a potential site for $\mathrm{N}$-glycosylation as do bovine and certain ovine IFN $\tau$ (Klemann et al., 1990).

Bovine IFN $\tau$ genes are approximately 30,50 and $75 \%$ identical in primary amino acid sequence to the IFN $\beta$, IFN $\alpha$ and IFN $\omega$, respectively, within the same species (Roberts $e t$ al., 1992). However, whereas the genes for the IFN $\omega$ are widely distributed among mammalian species, those for IFN $\tau$ seem to be restricted to the Ruminantia suborder of the Artiodactyla and probably evolved from the IFN $\omega$ between 30 and 65 million years ago (Leaman and Roberts, 1992). The IFN $\tau$ share a high degree of amino acid and nucleotide sequence identity and differ from the IFN $\omega$ in the $3^{\prime}$ non-coding regions of the genes (Roberts et al., 1991). It remains to be elucidated whether the $3^{\prime}$ end of cvIFN $\tau$ is more similar to the IFN $\omega$ or IFN $\tau$ of the Bovidae; and whether IFN $\tau$ is expressed only in the trophectoderm. An IFN $\tau$ gene has been isolated from genomic DNA of giraffe (Giraffa camelopardalis), a non-bovid species (Liu et al., 1996). This gene shows $>85 \%$ deduced amino acid sequence identity with bovine IFN $\tau$ and $>78 \%$ with $\operatorname{cvIFN} \tau$. Bovids (antelope and domestic species such as sheep, cows and goats), cervids (deer, pronghorns and moschids) and the Giraffidae (giraffe and okapi) are all members of the infraorder Pecora of the Ruminantia (Young, 1981). The presence of
IFN $\tau$ in all these groups suggests the evolution of this form of pregnancy signalling before the radiation of the separate families. It would be of interest to know whether the chevrotains express IFN $\tau$; if they did, this would imply that all Pecoran families have these characteristics.

The oestrous cycle of red deer shows many similarities to that of domestic ruminants, being characterized by well delineated follicular, luteal and luteolytic phases (Asher and Fisher, 1991). The non-pregnant red deer is seasonally polyoestrous, exhibiting regular 18 day cycles (Guinness et al., 1971), with the onset of the breeding season occurring during the autumn. In sheep, oxytocin secreted by the corpus luteum acts at uterine oxytocin receptors to stimulate pulses of endometrial $\mathrm{PGF}_{2 \alpha}$ secretion. The $\mathrm{PGF}_{2 \alpha}$ in turn acts on the corpus luteum to release further oxytocin in a utero-ovarian positive feedback interaction that culminates in luteolysis (for review, see Flint et al., 1992). The time at which luteal regression occurs is influenced by the time at which oxytocin receptors are generated in the uterus (Sheldrick and Flint, 1985). Spontaneous luteolysis in red deer has been shown to involve synchronous pulsatile secretion of oxytocin and $\mathrm{PGF}_{2 \alpha^{\prime}}$ and may be initiated by a similar positive feedback interaction between the uterus and the corpus luteum (Bainbridge and Jabbour, 1997). It is not yet known how IFN acts to prevent luteal regression in red deer, although IFN $\alpha$ treatment suppresses the pre-luteolytic increase in endometrial oxytocin sensitivity (Bainbridge et al., 1996; Bainbridge and Jabbour, 1997). Oxytocin receptor concentrations in the caruncular endometrium of red deer hinds are lower in pregnant than in non-pregnant hinds (Flint et al., 1997). IFN $\tau$ in red deer may block the stimulatory effect of circulating oxytocin on secretion of $\mathrm{PGF}_{2 \alpha}$ by inhibition of oxytocin receptor gene expression in the endometrium, as occurs in sheep (Mirando et al., 1993) and, as a result, the corpus luteum formed after ovulation becomes the corpus luteum of pregnancy.

The authors thank M-J. Searle, Royal Free Hospital, London, for assistance with the interferon assay; J. McVerry, MRC, Edinburgh, for help with the $18 \mathrm{~S}$ probe; M. Kaluzova and P. Fisher for help with the northern blot analysis and PCR; and staff at ADAS Rosemaund, Hereford for assistance with administering treatments and handling the deer. The financial support from MAFF is gratefully acknowledged. The sequence data contained in this paper is available in the EMBL nucleotide sequence database under the accession number AJ000638.

\section{References}

Abayasekara DRE, Sheldrick EL, Flicksmith HC and Flint APF (1995) Role of protein kinase $\mathrm{C}$ in the inhibitory action of trophoblast interferons on expression of the oxytocin receptor in sheep endometrium Endocrine 3 151-158

Asher GW and Fisher MW (1991) Reproductive physiology of farmed red deer (Cerous elaphus) and fallow deer (Dama dama). In Wildlife Production, Conservation and Sustainable Development pp 474-484 Eds LA Renecker and PJ Hudson. University of Alaska, Fairbanks

Asher GW, Fisher MW, Berg DK, Waldrup KA and Pearse AJ (1996) Luteal support of pregnancy in red deer (Cervus elaphus) - effect of cloprostenol, ovariectomy and lutectomy on the viability of the post-implantation embryo Animal Reproduction Science 41 141-151

Bainbridge DRJ and Jabbour HN (1997) Effect of pregnancy and exogenous interferon on synchronous pulsatile release of oxytocin and luteolytic 
prostaglandin $\mathrm{F}_{2 \alpha}$ in red deer (Cerous elaphus) Journal of Reproduction and Fertility 111 299-307

Bainbridge DRJ, Davies MH, Scaramuzzi RJ and Jabbour HN (1996) Exogenous interferon delays luteal regression in red deer hinds (Cervus elaphus) by suppressing steroid-induced endometrial oxytocin sensitivity Biology of Reproduction 55 883-888

Berg DK, Thompson JG, Pugh PA, Tervit HR and Asher GW (1995) Successful in vitro culture of early cleavage stage embryos recovered from superovulated red deer (Cervus elaphus) Theriogenology 44 247-254

Charlier M, Hue D, Martal J and Gaye P (1989) Cloning and expression of cDNA encoding ovine trophoblastin - its identity with a class-II alpha interferon Gene 77 341-348

Chomczynski P and Saachi N (1987) Single-step method of RNA isolation by acid guanidinium thiocyanate-phenol-chloroform extraction Analytical Biochemistry 162 156-159

Cross JC and Roberts R (1989) Porcine conceptuses secrete an interferon during the pre-attachment period of early pregnancy Biology of Reproduction 40 1109-1118

D'Andrea S, Chonstermans S, Flechon JE and La Bonnardiere C (1994) Paracrine activities of porcine trophoblastic interferons Journal of Reproduction and Fertility 102 185-194

Fennessy PF, Mackintosh CG and Shackell GH (1990) Artificial insemination of farmed red deer (Cervus elaphus) Animal Production 51 613-621

Fennessy PF, Asher GW, Beatson NS, Dixon TE, Hunter JW and Bringans MJ (1994) Embryo transfer in deer Theriogenology 41 133-138

Fincher KB, Bazer FW, Hansen PJ, Thatcher WW and Roberts RM (1986) Proteins secreted by the sheep conceptus suppress induction of uterine prostaglandin $\mathrm{F}_{2 \alpha}$ release by oestradiol and oxytocin Journal of Reproduction and Fertility $76425-433$

Flint APF (1995) Interferon, the oxytocin receptor and the maternal recognition of pregnancy in ruminants and non-ruminants - a comparative approach Reproduction, Fertility and Development 7313-318

Flint APF, Parkinson TJ, Stewart HJ, Vallet JL and Lamming GE (1991) Molecular biology of trophoblast interferons and studies of their effects invivo. Journal of Reproduction and Fertility Supplement 43 13-25

Flint APF, Stewart HJ, Lamming GE and Payne JH (1992) Role of the oxytocin receptor in the choice between cyclicity and gestation in ruminants Journal of Reproduction and Fertility Supplement 45 53-58

Flint APF, Lamming GE, Stewart HJ and Abayasekara DRE (1994) The role of the endometrial oxytocin receptor in determining the length of the sterile oestrous cycle and ensuring maintenance of luteal function in early pregnancy in ruminants Philosophical Transactions of the Royal Society of London Series B - Biological Sciences 344 291-304

Flint APF, Albon SD and Jafar SI (1997) Blastocyst development and conceptus sex selection in red deer, Cervus elaphus: studies of a free-living population on the Isle of Rhum General and Comparative Endocrinology 106 374-383

Godkin JD, Bazer FW, Moffatt J, Sessions F and Roberts RM (1982) Purification and properties of a major, low-molecular weight protein released by the trophoblast of sheep blastocysts at day 13-21 Journal of Reproduction and Fertility 65 141-150

Godkin JD, Bazer FW and Roberts RM (1984) Ovine trophoblast protein 1, an early secreted blastocyst protein, binds specifically to uterine endometrium and affects protein synthesis Endocrinology 114 120-130

Guinness F, Lincoln GA and Short RV (1971) The reproductive cycle of the female red deer, Cervus elaphus. Journal of Reproduction and Fertility 27 $427-438$

Hansen TR, Imakawa K, Polites HG, Marotti KR, Anthony RV and Roberts RM (1988) Interferon RNA of embryonic origin is expressed transiently during early pregnancy in the ewe Joumal of Biological Chemistry 263 12 801-12 804

Hansen TR, Leaman DW, Cross JC, Mathialagan N, Bixby JA and Roberts RM (1991) The genes for the trophoblast interferons and the related interferon-alpha-II possess distinct $5^{\prime}$-promoter and $3^{\prime}$-flanking sequences fournal of Biological Chemistry 266 3060-3067

Imakawa K, Anthony RV, Kazemi M, Marotti KR, Polites HG and Roberts RM (1987) Interferon-like sequence of ovine trophoblast protein secreted by embryonic trophectoderm Nature 330 377-379

Imakawa K, Hansen TR, Malathy PV, Anthony RV, Polites HG, Marotti KR and Roberts RM (1989) Molecular-cloning and characterisation of complementary deoxyribonucleic acids corresponding to bovine trophoblast protein-1 - a comparison with ovine trophoblast protein-1 and bovine interferon-alpha-II Molecular Endocrinology 3 127-139
IUCN (1996) IUCN Red List of Threatened Animals Eds J Baillie and B Groombridge, IUCN, Gland, Switzerland

Klemann SW, Imakawa K and Roberts RM (1990) Sequence variability among ovine trophoblast interferon cDNA Nucleic Acids Research 186724

Leaman DW and Roberts RM (1992) Genes for the trophoblast interferons in sheep, goat and musk ox and distribution of related genes among mammals Journal of Interferon Research 12 1-11

Liu LM, Leaman DW and Roberts RM (1996) The interferon-tau genes of the giraffe, a non-bovid species Journal of Interferon and Cytokine Research 16 949-951

McCracken JA, Carlson JC, Glew ME, Goding JR and Baird DT (1972) Prostaglandin F2 $\alpha$, identified as a luteolytic hormone in sheep Nature New Biology 238 129-134

Meager A (1987) Quantification of interferons by antiviral assays and their standardisation. In Lymphokines and Interferons: A Practical Approach pp 129-147 Eds M Clemens, AG Morris and AJH Gearing. IRL Press, Oxford

Mirando MA, Harney JP, Beers S, Pontzer CH, Torres BA, Johnson HM and Bazer FW (1990) Onset of secretion of proteins with anti-viral activity by pig conceptuses Journal of Reproduction and Fertility 88 197-203

Mirando MA, Harney JP, Zhou Y, Ogle TF, Ott TL, Moffatt RJ and Bazer FW (1993) Changes in progesterone and oestrogen receptor mRNA and protein and oxytocin receptors in endometrium of ewes after intra-uterine injection of ovine trophoblast interferon Journal of Molecular Endocrinology 10 185-192

Nephew KP, Whaley AE, Christenson RK and Imakawa K (1993) Differential expression of distinct messenger-RNAs for ovine trophoblast protein- 1 and related sheep type-I interferons Biology of Reproduction 48 768-778

Plante C, Thatcher WW and Hansen PJ (1991) Alteration of oestrous cycle length, ovarian function and oxytocin induced release of prostaglandin $\mathrm{F}_{2 \alpha}$ by intramuscular administration of recombinant bovine IFN- $\alpha$ to cows Journal of Reproduction and Fertility 93 375-384

Pontzer CH, Torres BA, Vallet JL, Bazer FW and Johnson HM (1988) Antiviral activity of the pregnancy recognition hormone ovine trophoblast protein-1 Biochemical and Biophysical Research Communications 152 801-807

Roberts RM (1989) A novel group of interferons associated with the early ovine and bovine embryo Journal of Interferon Research $9373-378$

Roberts RM, Imakawa K, Niwano Y, Kazemi M, Malathy PV, Hansen TR, Glass AA and Kronenberg LH (1989) Interferon production by the preimplantation sheep embryo Journal of Interferon Research 9 175-187

Roberts RM, Farin CE and Cross JC (1990) Trophoblast proteins and maternal recognition of pregnancy Oxford Reviews of Reproductive Biology 12 147-180

Roberts RM, Klemann SW, Leaman DW, Bixby JA, Cross JC, Farin CE, Imakawa K and Hansen TR (1991) The polypeptides and genes for ovine and bovine trophoblast protein-1 Journal of Reproduction and Fertility Supplement 43 3-12

Roberts RM, Cross JC and Leaman DW (1992) Interferons as hormones of pregnancy Endocrine Reviews 13 432-452

Sambrook J, Fritsch EF and Maniatis T (1989) Molecular Cloning: A Laboratory Manual Cold Spring Harbor Laboratory Press, Cold Spring Harbor, NY

Shafferman A, Velan B, Cohen S, Leitner M and Grosfeld H (1987) Specific residues within an amino-terminal domain of 35 residues of interferon-alpha are responsible for recognition of the human interferon-alpha cell-receptor and for triggering biological effects Journal of Biological Chemistry 262 6227-6237

Sheldrick EL and Flint APF (1985) Luteal oxytocin and the control of prostaglandin $F_{2 \alpha}$ secretion during luteolysis in ewes Journal of Endocrinology Supplement 10789

Stewart HJ, Flint APF, Lamming GE, McCann SHE and Parkinson TJ (1989a) Anti-luteolytic effects of blastocyst secreted interferon investigated in vitro and in vivo in the sheep Journal of Reproduction and Fertility Supplement 37 127-138

Stewart HJ, McCann SHE, Northrop AJ, Lamming GE and Flint APF (1989b) Sheep anti-luteolytic interferon - cDNA sequence and analysis of mRNA levels Journal of Molecular Endocrinology 265-70

Waldhalm SJ, Jacobson HA, Dhungel SK and Bearden HJ (1989) Embryo transfer in the white-tailed deer - a reproductive model for endangered deer species of the world Theriogenology $31437-450$

Wetzel R (1981) Assignment of the disulphide bonds of leukocyte interferon Nature 289 606-607

Wildt DE (1992) Genetic resource banks for conserving wildlife species: justification, examples and becoming organised on a global basis Animal Reproduction Science 28 247-257

Young JZ (1981) The Life of Vertebrates Oxford University Press, Oxford 